\title{
Meningkatkan Keaktifan Peserta Didik Dengan Strategi Pembelajaran Kooperatif Melalui Layanan Bimbingan Klasikal
}

\author{
Nuriska Wahyu Utami \\ Mahasiswa Pascasarjana
}

Program Studi Magister Pedagogi

Universitas Pancasakti Tegal Jawa Tengah, Indonesia

\begin{abstract}
Abstrak
Tujuan meningkatkan keaktifan peserta didik dalam layanan bimbingan klasikal dengan strategi pembelajaran kooperatif. Dalam interaksi konselor dengan peserta didik terdapat beberapa peserta didik tidak bisa manyampaikan aspirasinya karena terhalang oleh dominasi peserta didik yang lain ketika disituasi kelas klasikal. Kelompok dalam jumlah besar menimbulkan rasa tidak percaya diri peserta didik karena takut salah dalam mengutarakan ide atau hasil pemikirannya. Sehingga secara otomatis siswa kehilangan kesempatan untuk aktif berpendapat atau menjawab pertanyaan dari pendidik. Selain itu tentunya sering pula dijumpai peserta didik yang tidak seluruhnya aktif, masih ada yang belum aktif dan terlibat dalam preoses pembelajaran yang dilaksanakan. Keaktifan mengikuti bimbingan klasikal dapat memberikan stimulus kepada peserta didik didalam kelas untuk selalu aktif secara fisik, intelektual, emosi. Tentunya dibutuhkan sebuah startegi yang cocok untuk meningkatkan keaktifan peserta didik pada proses pelayanan bimbingan klasikal. Salah satu strategi yang cocok pada masalah ini adalah menggunakan pembelajaran kooperatif yang sering disebut dengan pembelajaran berkelompok.
\end{abstract}

Kata Kunci: Aktif, Layanan Bimbingan Klasikal, Strategi Pembelajaran Kooperatif

\begin{abstract}
The goal is to increase the activeness of students in classical guidance services with cooperative learning strategies. In the counselor's interaction with students, there are some students who cannot express their aspirations because they are hindered by the dominance of other students in classical classroom situations. Groups in large numbers cause students to feel insecure because they are afraid of being wrong in expressing their ideas or thoughts. So that automatically students lose the opportunity to actively argue or answer questions from educators. In addition, of course, there are often students who are not entirely active, there are still students who are not active and involved in the learning process carried out. The activity of following classical guidance can provide a stimulus to students in the class to always be active physically, intellectually, emotionally. Of course, a suitable strategy is needed to increase the activeness of students in the process of classical guidance services. One strategy that is suitable for this problem is to use cooperative learning which is often referred to as group learning
\end{abstract}

Keywords: Active, Classical Tutoring Services, Cooperative Learning Strategies 


\section{Pendahuluan}

Bimbingan klasikal merupakan layanan bimbingan yang diberikan kepada siswa dalam jumlah satuan kelas atau suatu layanan bimbingan yang diberikan oleh guru bimbingan dan konseling/konselor kepada sejumlah peserta didik dalam satuan kelas yang dilaksanakan di ruang kelas. Sejalan dengan Winkel dan Hastuti (2004), melalui bimbingan klasikal para siswa dapat memperoleh manfaat bahwa setiap siswa dapat berpartisipasi dalam kelompok, sekalipun mereka mungkin tidak memilih untuk berbicara dalam kelompok. Selain itu siswa lebih berani mengemukakan pandangannya sendiri bila berada dalam kelompok.

Bimbingan klasikal merupakan salah satu strategi dalam layanan bimbingan dan konseling yang digunakan oleh guru bimbingan dan konseling untuk mengatasi jumlah peserta didik yang jumlah rasionya jauh lebih banyak dari guru bimbingan dan konseling. Bimbingan klasikal merupakan layanan bimbingan dan konseling untuk memberikan peserta didik tentang data maupun fakta dalam bidang belajar, karir, pribadi dan sosial agar peserta didik dapat belajar tentang lingkungannya yang akhirnya dengan pengetahuan tersebut peserta didik mampu untuk mengatur dan merencanakan hidupnya.

Pendapat ini menyatakan bahwa layanan bimbingan klasikal membantu peserta didik secara tidak langsung pada proses perencanaan hidupnya dengan materi yang diberikan syarat dengan ilmu pengetahuan mengenai belajar, karir, sosial dan pribadi. Peserta didik saat diberikan layananan bimbingan klasikal yang berisi informasi luas harus diberikan pemahaman terkait informasi yang relevan untuk mereka gunakan dan informasi yang tidak relevan serta informasi yang menyangkut data yang tidak berubah dan dapat berubah seiring dengan berjalannya waktu.

Layanan bimbingan dan klasikal pada dasarnya dapat diberikan dengan berbagai macam metode. Pemberian dengan berbagai metode bisa disesuaikan dengan materi, keadaan kelas atau pada hari-hari khusus. Layanan bimbingan klasikal bisa diberikan dengan metode sama seperti guru kelas pada umumnya. Penentuan metode diputuskan oleh guru bimbingan dan konseling untuk mendukung peningkatan pengetahuan peserta didik dalam mengikuti materi yang diampaikan. Menurut Tohirin (2016) layanan bimbingan klasikal (informasi) merupakan layanan yang dapat diberikan dengan berbagai metode yaitu; (1) ceramah, tanya jawab dan diskusi; (2) melalui media; (3) acara khusus; (4) narasumber.

Prayitno dan Amti (2004) menyebutkan bahwa bimbingan klasikal diselenggarakan oleh guru pembimbing selaku konselor sekolah untuk memberikan informasi yang bersifat karier, belajar, dan personal-sosial. Ketiga sifat informasi tersebut menunjuk pada bidang kehidupan siswa sebagai ragam bimbingan klasikal yaitu personal-sosial, belajar, dan bidang karier.

Dalam interaksi konselor dengan peserta didik terdapat beberapa peserta didik tidak bisa manyampaikan aspirasinya karena terhalang oleh dominasi peserta didik yang lain ketika disituasi kelas klasikal. Kelompok dalam jumlah besar menimbulkan rasa tidak percaya diri peserta didik 
karena takut salah dalam mengutarakan ide atau hasil pemikirannya. Sehingga secara otomatis siswa kehilangan kesempatan untuk aktif berpendapat atau menjawab pertanyaan dari pendidik. Selain itu tentunya sering pula dijumpai peserta didik yang tidak seluruhnya aktif, masih ada yang belum aktif dan terlibat dalam preoses pembelajaran yang dilaksanakan.

Kekurangaktifan siswa yang terlibat dalam proses layanan klasikal di kelas dapat terjadi karena strategi pemberian layanan yang digunakan konselor kurang melibatkan siswa secara langsung. Dalam artian pembelajaran masih berpusat kepada konselor/guru. Model pembelajaran yang digunakan konselor sangat berpengaruh dalam menciptakan situasi belajar yang benar-benar menyenangkan dan mendukung kelancaran proses pemberian materi layanan, serta sangat membantu dalam pencapaian pemahaman materi yang memuaskan. Sehingga disini dibutuhkan strategi layanan yang dapat peserta didik menjadi aktif pada saat pemberian layanan.

Kompetensi yang dimiliki konselor sangatlah mempengaruhi kualitas keaktifan pelayanan yang dilaksanakan. Keaktifan mengikuti bimbingan klasikal dapat memberikan stimulus kepada peserta didik didalam kelas untuk selalu aktif secara fisik, intelektual, emosi. Tentunya dibutuhkan sebuah startegi yang cocok untuk meningkatkan keaktifan peserta didik pada proses pelayanan bimbingan klasikal. Salah satu strategi yang cocok pada masalah ini adalah menggunakan pembelajaran kooperatif yang sering disebut dengan pembelajaran berkelompok.

Strategi Pembelajaran Kooperatif (SPK) merupakan model pembelajaran dengan menggunakan sistem pengelompokan/tim kecil, yaitu antara empat sampai enam orang yang mempunyai latar belakang yang berbeda-beda (heterogen), baik kemampuan akademik, jenis kelamin, ras atau suku. Dengan sistem penilaian dimana setiap kelompok akan memperoleh penghargaan (reward), jika kelompok mampu menunjukkan prestasi yang dipersyaratkan. Dengan demikian, setiap anggota kelompok akan mempunyai ketergantungan positif yaitu setiap individu secara aktif mempunyai motivasi untuk keberhasilan kelompok, sehingga setiap individu akan memiliki kesempatan yang sama untuk memberikan kontribusi demi keberhasilan kelompoknya (https://www.misjuli.com/2015/02/macam-macam-strategi-pembelajaran-dan.html)

Pembelajaran Kooperatif merupakan salah satu model pembelajaran kelompok yang memiliki aturan-aturan tertentu. Prinsip dasar pembelajaran kooperatif adalah siswa membentuk kelompok kecil dan saling mengajar sesamanya untuk mencapai tujuan bersama. Dalam pembelajaran kooperatif siswa pandai mengajar siswa yang kurang pandai tanpa merasa dirugikan. Siswa kurang pandai dapat belajar dalam suasana yang menyenangkan karena banyak teman yang membantu dan memotivasinya. Siswa yang sebelumnya terbiasa bersikap pasif setelah menggunakan pembelajaran kooperatif akan terpaksa berpartisipasi secara aktif agar bisa diterima oleh anggota kelompoknya. Hal tersebut sejalan dengan Chandra Ertikanto yang mengutip pendapat Muslim dalam Widyanti (2016) Pembelajaran kooperatif adalah model pembelajaran yang mengutamakan adanya kerjasama antarsiswa dalam kelompok adalah rangkaian kegiatan 
pembelajaran yang dilakukan oleh siswa dalam kelompok-kelompok tertentu, dimana siswa belajar bersama, saling menyumbangkan pikiran dan bertanggungjawab terhadap pencapaian hasil pembelajaran.

Tujuan strategi pembelajaran kooperatif adalah agar hasil belajar akademik peserta didik meningkat dan dapat menerima berbagai keragaman dari temannya serta pengembangan ketrampilan sosial. Adapun yang mendasari tujuan pembelajaran kooperatif adalah adanya 1) Saling ketergantungan positif 2) Interaksi tatap muka 3) Akuntabilitas individual.

\section{Pembahasan}

Pembelajaran kooperatif melalui layanan bimbingan klasikal peserta didik dapat saling berbagi bertukar pikiran, dapat bekerja sama, saling bergantung secara positif dan saling bertanggung jawab. Sehingga peserta didik mampu mengikuti dengan baik dan dengan secara terus menerus mengikutinya dapat membuat peserta didik selalu menyimak sehingga akan selalu siap jika harus dituntut aktif dalam proses pembelajaran, dengan menyimak peserta didik akan yakin terhadap kepercayaan dirinya sehingga merasa yakin dan merasa bisa dengan sendirinya tanpa menggantungkannya kepada peserta didik lainya karena dirinya sudah menganggap dirinya sendiri bisa sendiri. Dalam pembelajaran kooperatif memiliki enam macam kategori pembagianya dilandasi oleh tujuan prinsipnya yang pertama yaitu pembangunan kebersamaan dalam kelas, pembangunan kebersamaan sebagai anggota tim, keterampilan berkomunikasi, keterampilan berpikir, pertukaran informasi dan penguasaan materi.

Dengan menggunakan strategi pembelajaran koorperatif (SPK) melalui layangan bimbingan klasikal banyak sekali manfaat yang diperoleh baik untuk konselor maupun peserta didik dalam mamancing siswa untuk aktif dalam materi yang diberikan. Yaitu, meningkatkan kemampuan siswa untuk berfikir. Kemudian siswa juga dapat mencari informasi dari sumber lain (buku panduan, buku perpustakan dan buku lainya ataupun dari internet) ataupun dari teman kelompoknya, sehingga tidak hanya mengandalkan informasi materi dari konselor saja. Selanjutnya yaitu menjadikan siswa lebih menghormati dan menghargai pendapat siswa lainya. Dengan adanya perbedaan pendapat dan masukan mereka mendapatkan titik temu dan kesimpulan pada hal yang diperdebatkan kemudian menghasilkan hasil akhir yang didiskusikan.

Strategi Kooperatif yang dilakukan melalui layanan bimbingan klasikal dengan benar akan dapat menimbulkan saling ketergantungan positif antar anggota kelompok, sehingga secara otomatis akan terjalin kerjasama yang saling menguntungkan. Selain itu, aktivitas kelompok dilakukan bersama-sama sehingga terjadi interaksi langsung dengan tatap muka. Interaksi langsung dalam bentuk tatap muka dapat membangun kebersamaan diantara anggota kelompok disertai dengan ikatan emosional yang lebih erat. Sikap empatik dan simpatik diantara para siswa dapat timbul karena adanya interaksi secara langsung yang lebih intens. Demikian pula, 
pembagian tugas dalam kelompok akan berdampak terhadap tumbuhnya pertanggungjawaban pribadi masing-masing anggota. Hal ini terjadi karena pembelajaran kooperatif setiap individu mendapat tugas untuk belajar dan berkewajiban menyampaikan kepada anggota lain. Pada akhirnya pembelajaran kooperatif yang terjadi proses interaksi antar individu yang menuntut komunikasi interpersonal yang baik, sehingga terjalin hubungan yang harmonis dan kondusif dalam kelas (Sutirman, 2013).

Selain itu, keuntungan pemberian layanan bimbingan klasikal menggunakan pembelajaran kooperatif yaitu kerja kelompok yang diberikan oleh pendidik, hal ini memungkinkan pendidik untuk mengelola kelas besar lebih efektif. Hal ini mendorong kerjasama, keterampilan sosialisasi dikembangkan. Peserta didik belajar untuk berbagi dan menghormati satu sama lain dan bekerjasama. Percaya diri dipromosikan, keterampilan komunikasi dikembangkan. Hal ini berpusat pada peserta didik, peserta didik yang aktif dan terlibat. Kelompok dengan anggota kemampuan serupa dapat bekerja pada kecepatan mereka sendiri, peserta didik dapat belajar mengendalikan diri dan disiplin diri.

\section{Simpulan}

Strategi Pembelajaran Kooperatif (SPK) selain harapan memiliki dampak pemberian layanan bimbingan konseling yang positif berupa peningkatan keaktifan siswa dalam kegiatan pemberian materi, maka diharapkan ada dampak positif yang lain seperti relasi sosial, penerimaan terhadap peserta didik yang dianggap lemah, harga diri, norma akademik, penghargaan terhadap waktu, dan suka memberi pertolongan pada yang lain. Sehingga dapat berguna untuk proses perkembangannya dimasa yang akan datang.

\section{Daftar Pustaka}

Chandra Ertikanto, 2016. Teori Belajar dan Pembelajaran. Yogyakarta : Media Akademi

https://www.misjuli.com/2015/02/macam-macam-strategi-pembelajaran-dan.html

Prayitno dan Amti, 2004. Dasar-Dasar Bimbingan dan Konseling. Jakarta:Rineke Cipta

Sutirman, 2013. Media \& Model-model Pembelajaran Inovatif. Yogyakarta: Graha Ilmu

Tohirin, 2016. Bimbingan Konseling Di Sekolah Dan Madrasah Berbasis Integrasi. Jakarta : Raja Grafindo 1. $366 \mathrm{Hal}$

Winkel dan Hastuti, 2004. Bimbingan dan Konseling di Institusi Pendidikan .Yogyakarta: Media Abadi 